\title{
The 100 most cited articles investigating the radiological staging of oesophageal and junctional cancer: a bibliometric analysis
}

\author{
Kieran G. Foley ${ }^{1} \cdot$ Arfon Powell $^{2} \cdot$ Wyn G. Lewis $^{2} \cdot$ Stuart Ashley Roberts $^{3}$
}

Received: 23 March 2016 /Revised: 18 May 2016 / Accepted: 24 May 2016 / Published online: 8 June 2016

(C) The Author(s) 2016. This article is published with open access at Springerlink.com

\begin{abstract}
Objectives Accurate staging of oesophageal cancer (OC) is vital. Bibliometric analysis highlights key topics and publications that have shaped understanding of a subject. The 100 most cited articles investigating radiological staging of $\mathrm{OC}$ are identified.

Methods The Thomas Reuters Web of Science database with search terms including "CT, PET, EUS, oesophageal and gastro-oesophageal junction cancer" was used to identify all English language, full-script articles. The 100 most cited articles were further analysed by topic, journal, author, year and institution.

Results A total of 5,500 eligible papers were returned. The most cited paper was Flamen et al. $(n=306)$, investigating the utility of positron emission tomography (PET) for the staging of patients with potentially operable OC. The most common research topic was accuracy of staging investigations $(n=63)$. The article with the highest citation rate (38.00), defined as the number of citations divided by the number of complete years published, was Tixier et al. investigating PET texture analysis to predict treatment response to neoadjuvant chemo-radiotherapy, cited 114 times since publication in 2011.

Conclusion This bibliometric analysis has identified key publications regarded as important in radiological OC staging. Articles with the highest citation rates all investigated PET
\end{abstract}

Kieran G. Foley

foleykg@cardiff.ac.uk

Division of Cancer \& Genetics, Cardiff University, Cardiff, UK

Department of Surgery, University Hospital of Wales, Cardiff, UK

3 Department of Radiology, University Hospital of Wales, Cardiff, UK imaging, suggesting this modality could be the focus of future research.

Main Messages

- This study identifies key articles that investigate radiological staging of oesophageal cancer.

- The most common topic was accuracy of staging investigations.

- The article with the highest citation rate investigated the use of texture analysis in PET images.

Keywords Bibliometric analysis · Oesophageal cancer . Gastro-oesophageal junction cancer · TNM staging · Citation

\section{Introduction}

Bibliometric analysis assesses the number of times that an article is cited in the literature, and in which particular journal. A citation is received when an article references another peerreviewed publication. An article that is felt to have greater importance and higher impact by the scientific community is more likely to be cited and therefore may be more influential on current healthcare practice. Articles and journals can be ranked based on the number of citations they receive. Bibliometric analysis also reveals topics of current interest, identifies potential novel techniques and shows historical developments in that subject [1]. Medical researchers have used bibliometric analysis to identify the most influential papers in their clinical specialties, including orthopaedic surgery [2] and oncology [3].

Worldwide, the prognosis of oesophageal cancer, including gastro-oesophageal junction cancer (OC), is poor. Overall 5year survival in the UK is approximately $13 \%$ [4]. As a part of the diagnostic pathway, patients undergo a variety of staging investigations to assess the extent of disease. Radiological 
staging is performed to further inform management decisions by the multi-disciplinary team (MDT). Accurate radiological staging is vital to ensure the most appropriate treatment is selected. Currently, OC is staged according to the International Union Against Cancer (UICC) Tumour Node Metastasis (TNM) 7th edition [5].

In the UK, patients with OC are initially staged with CT of the thorax and abdomen to exclude irresectable disease or distant metastases. If the patient is deemed suitable for radical treatment, either in the form of definitive chemo-radiotherapy (dCRT) or surgery ( \pm neo-adjuvant therapy), positron emission tomography combined with computed tomography (PET/CT) and endoscopic ultrasound (EUS) are performed for a more detailed assessment of disease stage [6].

This bibliometric analysis of OC staging investigations aims to identify key research that has influenced staging methods, the institutions leading this research, studies that may change staging methods in the future and imaging modalities being focused upon.

\section{Materials and methods}

The Thomas Reuters Web of Science citation indexing database was used to perform the search. The following search terms were used in order to capture the variety of imaging modalities and the different nomenclature of tumours: (oesophag* AND (neoplas* OR cancer* OR carcin* OR tumo* OR malig*)) OR (esophag* AND (neoplas* OR cancer* OR carcin* OR tumo* OR malig*)) OR (gastro-oesophageal junction AND (neoplas* OR cancer* OR carcin* OR tumo* OR malig*)) OR (oesophago-gastric junction AND (neoplas* OR cancer* OR carcin* OR tumo* OR malig*) AND (computed tomography OR CT OR CAT) OR (positron emission tomography OR PET OR F18 OR FDG OR fluorodeoxyglucose) OR (endoscopic ultrasonography OR endoscopic ultrasound OR endosonographic OR EUS) OR (magnetic resonance imaging OR MRI or diffusion weight* OR DWI) AND (stag* OR TNM OR lymph node OR metasta*). The search was performed on 18 September 2015.

All databases within the Thomas Reuters Web of Science were searched. The results were filtered to include only full script articles written in the English language, throughout all available years. The results were sorted by number of citations, with the article with most citations analysed first. The method was developed by Paladugu et al. [7].

The title and abstract of the returned articles were manually assessed to ensure that their relevance and content were in keeping with this field. The inclusion criterion was that the article investigated the use of a single or combination of radiological modalities in patients with OC. This criterion was pre-specified and defined prior to data collection.
Articles were excluded from the list if the content was not relevant to radiological OC staging. The 100 most cited articles were identified and further analysed.

The articles were further evaluated for the publishing journal, names of the first and senior author, the institution and department to which the first author was affiliated, the country of origin, year of publication, the radiological investigation(s) being studied, the topic of the article and the number of citations according to Web of Science. Rank within the top 100 articles was also recorded.

Articles have the opportunity to accrue more citations if they have been published for longer. To adjust for this, a citation rate was calculated, defined as the number of citations divided by the number of complete years published. A list of the ten articles with the highest citation rates is provided.

In addition, the individual and 5-year impact factors in 2014 were recorded for the publishing journal. The overall median 2014 and 5-year impact factor for all journals was calculated.

\section{Results}

The Web of Science search returned 5,500 full articles, written in English language. The 100 most cited articles are listed in Table 1 [8-107].

The article with the highest number of citations $(n=306)$ was Flamen et al. [8], entitled 'Utility of positron emission tomography for the staging of patients with potentially operable oesophageal carcinoma'. The article ranked 100 in the list was Wu et al. [107], entitled 'Preoperative TN staging of oesophageal cancer: comparison of miniprobe ultrasound, spiral CT and MRI', with 46 citations.

The oldest article was published in 1979 by Daffner et al. [71] 'CT of the Oesophagus. 2. Carcinoma'. Tixier et al. [47] published the most recent paper in the list in 2011, entitled 'Intratumor Heterogeneity Characterized by Textural Features on Baseline F-18-FDG PET Images Predicts Response to Concomitant Radiochemotherapy in Esophageal Cancer', which has been cited 114 times.

The journal with the highest number of published articles was Gastrointestinal Endoscopy (Table 2). Fourteen articles were published with a total of 1675 citations [11, 16, 34, 38, $48,59,62,63,66,76,80,82,83,85]$. The 2014 impact factor of the Gastrointestinal Endoscopy was 5.369, with 5-year impact factor 5.225. The journal with the highest impact factor was the Journal of Clinical Oncology (JCO), which had a total of 1,258 citations $[8,12,15,18,23,70]$. Five of these six articles were investigating PET imaging. The 2014 impact factor of JCO was 18.428, with 5-year impact factor 16.996. Overall, the median 2014 impact factor of the journals was 5.238 and median 5-year impact factor was 5.225. 
Table 1 The 100 most cited articles in radiological staging of oesophageal and junctional cancer

\begin{tabular}{|c|c|c|c|c|c|}
\hline \multirow{2}{*}{\multicolumn{3}{|c|}{ oesophageal and junctional cancer }} & \\
\hline & & & Rank & Number of Citations & First author \\
\hline Rank & Number of Citations & First author & 46 & 105 & Wallace MB [56] \\
\hline 1 & 306 & Flamen P [8] & 50 & 104 & Quint LE [57] \\
\hline 2 & 294 & Tio TL [9] & 51 & 103 & Kato H [58] \\
\hline 3 & 290 & Kinkel K [10] & 51 & 103 & Larghi A [59] \\
\hline 4 & 273 & Catalano MF [11] & 53 & 102 & Takashima S [60] \\
\hline 5 & 271 & Wieder HA [12] & 54 & 100 & van Westreenen HL [61] \\
\hline 6 & 261 & Botet JF [13] & 55 & 98 & Eloubeidi MA [62] \\
\hline 7 & 242 & Skinner DB [14] & 55 & 98 & Hasegawa N [63] \\
\hline 8 & 229 & Ott K [15] & 57 & 96 & Levine EA [64] \\
\hline 9 & 221 & Bhutani MS [16] & 57 & 96 & Rice TW [65] \\
\hline 10 & 201 & Flamen P [17] & 59 & 92 & Isenberg G [66] \\
\hline 11 & 193 & Downey RJ [18] & 59 & 92 & Leong T [67] \\
\hline 12 & 192 & Flanagan FL [19] & 59 & 92 & Puli SR [68] \\
\hline 13 & 189 & Picus D [20] & 62 & 91 & Flamen P [69] \\
\hline 14 & 184 & Rosch T [21] & 62 & 91 & Lightdale CJ [70] \\
\hline 15 & 183 & Kelly S [22] & 64 & 89 & Daffner RH [71] \\
\hline 16 & 168 & van Westreenen HL [23] & 64 & 89 & Kim K [72] \\
\hline 17 & 165 & May A [24] & 64 & 89 & Meltzer CC [73] \\
\hline 18 & 164 & Lerut $\mathrm{T}[25]$ & 64 & 89 & Vrieze O [74] \\
\hline 19 & 160 & Kato H [26] & 68 & 88 & Jones DR [75] \\
\hline 20 & 159 & Block MI [27] & 69 & 86 & Chak A [76] \\
\hline 20 & 159 & Swisher SG [28] & 70 & 84 & Hyun SH [77] \\
\hline 22 & 157 & Swisher SG [29] & 70 & 84 & Quint LE [78] \\
\hline 23 & 150 & Luketich JD [30] & 72 & 83 & Murata Y [79] \\
\hline 24 & 146 & Rice TW [31] & 73 & 82 & Hiele M [80] \\
\hline 24 & 146 & Vilgrain V [32] & 74 & 80 & Wakelin SJ [81] \\
\hline 26 & 145 & van Vliet EPM [33] & 75 & 79 & Scotiniotis IA [82] \\
\hline 27 & 143 & Rosch T [34] & 76 & 78 & Fockens P [83] \\
\hline 28 & 137 & Ziegler K [35] & 77 & 76 & Beseth BD [84] \\
\hline 29 & 136 & Kole AC [36] & 77 & 76 & Catalano MF [85] \\
\hline 30 & 135 & Luketich JD [37] & 77 & 76 & Giovannini M [86] \\
\hline 31 & 133 & Buskens CJ [38] & 80 & 75 & Rice TW [87] \\
\hline 32 & 132 & Watt I [39] & 81 & 74 & Heeren PAM [88] \\
\hline 33 & 130 & Moss AA [40] & 81 & 74 & Rizk N [89] \\
\hline 34 & 123 & Zuccaro G [41] & 83 & 72 & Kostakoglu L [90] \\
\hline 35 & 122 & Grimm H [42] & 83 & 72 & Moureau-Zabotto L [91] \\
\hline 36 & 121 & Vazquez-Sequeiros E [43] & 85 & 70 & Pech O [92] \\
\hline 37 & 116 & Yoon YC [44] & 86 & 69 & Choi JY [93] \\
\hline 38 & 115 & Tio TL $[45]$ & 86 & 69 & Lehr L [94] \\
\hline 39 & 114 & Cerfolio RJ [46] & 86 & 69 & Lightdale CJ [95] \\
\hline 39 & 114 & Tixier F [47] & 89 & 68 & Kobori D [96] \\
\hline 41 & 113 & Vazquez-Sequeiros E [48] & 89 & 68 & Luketich JD [97] \\
\hline 42 & 112 & Dittler HJ [49] & 91 & 67 & Lowe VJ [98] \\
\hline 43 & 111 & Rasanen JV [50] & 92 & 62 & Song SY [99] \\
\hline 44 & 108 & Quint LE [51] & 92 & 62 & Yuan S [100] \\
\hline 45 & 107 & Reed CE [52] & 94 & 61 & Bar-Shalom R [101] \\
\hline 46 & 105 & Choi JY [53] & 94 & 61 & McAteer D [102] \\
\hline 46 & 105 & Rankin SC [54] & 94 & 61 & van Westreenen HL [103] \\
\hline 46 & 105 & Thompson WM [55] & 97 & 60 & Eloubeidi MA [104] \\
\hline
\end{tabular}

Table 1 (continued) 
Table 1 (continued)

\begin{tabular}{lll}
\hline Rank & Number of Citations & First author \\
\hline 97 & 60 & Konski A [105] \\
99 & 59 & Meyers BF [106] \\
100 & 46 & Wu LF [107] \\
\hline
\end{tabular}

Twenty-nine of the 100 articles were published in a radiology-related journal, including nuclear medicine and radiation oncology journals. Thirty-five of the first authors were affiliated to a radiology, nuclear medicine or radiation oncology department, according to the Thomas Reuters Web of Science citation indexing database. Three radiology-related journals, with 5-year impact factor $>5.00$, published 16 articles in the top 100. These were Radiology (5-year impact factor 7.259; $\mathrm{n}=6$ ), Journal of Nuclear Medicine (5-year impact factor $6.280 ; n=8)$ and European Journal of Nuclear Medicine and Molecular Imaging (5-year impact factor 5.090; $\mathrm{n}=1$ ).

Researchers from the USA published the greatest number of articles in the 100 most cited $(n=47)[11,13,14,16,18-20$, 27-31, 37, 40, 41, 43, 46, 48, 51, 52, 55-57, 59, 62, 64-66, $68,70,71,73,75,76,78,82,84,85,87,89,90,95,97,98$, 104-106], jointly followed by Germany [12, 15, 21, 24, 34, $35,42,49,92,94]$ and The Netherlands [9, 23, 33, 36, 38, 45, $61,83,88,103](\mathrm{n}=10$, each) (Table 3). The Technical University of Munich, Germany, was the institution with the joint highest number of publications in the 100 Most Cited $(n=6)$ and the highest number of citations $(1,008)[12,15,21$, 34, 49, 94]. The University Hospital Gasthuisberg, Leuven, Belgium, also had 6 published articles, with a total of 933 citations $[8,17,25,69,74,80]$. The most cited article was from this institution [8] and written by Dr Patrick Flamen (first
Table 3 Number of articles per country of origin in 100 most cited

\begin{tabular}{ll}
\hline Country & Total number of articles \\
\hline USA & 47 \\
Germany & 10 \\
The Netherlands & 10 \\
Belgium & 6 \\
Japan & 6 \\
South Korea & 6 \\
UK & 5 \\
France & 4 \\
China & 2 \\
Australia & 1 \\
Finland & 1 \\
Israel & 1 \\
Switzerland & 1 \\
\hline
\end{tabular}

author) with Prof. Luc Mortelmans as senior author. Dr Flamen has 3 first author articles in the 100 most cited [8, 17, 69] and a total of 598 citations. Prof. Mortelmans has 4 articles published as senior author [8, 17, 25, 69] and a total of 762 citations.

The most common researched topic was the accuracy of radiological staging investigations $(n=63)$ (Table 4). Several of the study themes overlapped but accuracy of staging was commonly compared between different modalities $(n=29)$. The investigation of lymph node metastases $(n=15)$ and radiological response to treatment $(n=14)$ were also commonly cited topics.

EUS was the most common modality investigated $(n=51)$, with PET/CT $(n=48)$ and CT $(n=46)$ following. The combination of CT, EUS and PET/CT was commonly investigated

Table 2 Journals with $\geq 2$ articles in 100 most cited

\begin{tabular}{|c|c|c|c|c|}
\hline Journal & Number of articles & 2014 Impact factor & 5-Year impact factor & Total number of citations \\
\hline Gastrointestinal Endoscopy & 14 & 5.369 & 5.225 & 1,675 \\
\hline Annals of Thoracic Surgery & 9 & 3.849 & 4.104 & 1,038 \\
\hline Journal of Nuclear Medicine & 8 & 6.16 & 6.280 & 657 \\
\hline Cancer & 7 & 5.238 & 5.517 & 830 \\
\hline American Journal of Roentgenology & 6 & 2.731 & 3.302 & 764 \\
\hline Journal of Clinical Oncology & 6 & 18.428 & 16.966 & 1,258 \\
\hline Radiology & 6 & 6.867 & 7.259 & 1,044 \\
\hline Endoscopy & 5 & 5.053 & 4.855 & 494 \\
\hline Journal of Thoracic and Cardiovascular Surgery & 5 & 4.168 & 4.068 & 428 \\
\hline Annals of Surgery & 3 & 8.327 & 8.844 & 502 \\
\hline Gut & 3 & 14.66 & 12.553 & 485 \\
\hline International Journal of Radiation Oncology Biology Physics & 3 & 4.258 & 4.359 & 194 \\
\hline American Journal of Gastroenterology & 2 & 10.755 & 9.145 & 193 \\
\hline Annals of Surgical Oncology & 2 & 3.93 & 4.532 & 195 \\
\hline British Journal of Cancer & 2 & 4.836 & 5.305 & 281 \\
\hline Gastroenterology & 2 & 16.716 & 13.811 & 415 \\
\hline Radiotherapy and Oncology & 2 & 4.363 & 4.502 & 181 \\
\hline World Journal of Gastroenterology & 2 & 2.369 & 2.671 & 138 \\
\hline
\end{tabular}


together, which is the recommended staging pathway for potentially curable disease in the UK $(\mathrm{n}=11)[8,25,28,31,50$, $53,88,98,105]$. MRI $(n=5)$, bone scintigraphy $(n=2)$, PET alone $(\mathrm{n}=1)$, EUS-FNA $(\mathrm{n}=1)$, US $(\mathrm{n}=1)$ and laparoscopic US $(n=1)$ were also cited.

The article with the highest citation rate (38.00) was Tixier et al. [47], published in 2011 and investigated texture analysis in OC. The ten articles with the highest citation rates were published between 2002 and 2011 and all involved investigation of PET images (Table 5). Four of the articles investigated treatment response $[12,15,18,47]$. An international collaboration collecting data that informed the International Union Against Cancer (UICC) Tumour Node and Metastasis (TNM) 7th edition [31] had the second highest citation rate (36.50). Five of the ten articles with the highest citation rates were published in the Journal of Clinical Oncology, which had the highest impact factor (5-year 16.971).

\section{Discussion}

OC is the eighth most common malignancy worldwide, resulting in around 400,000 deaths per annum [108]. This study demonstrates that accuracy of staging was the most frequently studied topic $(n=63)$ (Table 4). Accurate staging investigations are vital to inform appropriate treatment decisions, providing the best chance of survival for the patient whilst minimising harm from over- or under-treatment. The most cited article was Flamen et al. [8], which investigated the use of PET in potentially operable OC.

Table 4 Most frequently cited topics of investigation (numbers do not add up to 100 as there are different combinations of topics in the articles)

\begin{tabular}{ll}
\hline Topic & Number of articles \\
\hline Accuracy of staging & 63 \\
Comparison of imaging modalities & 29 \\
Lymph node metastases & 15 \\
Treatment response & 14 \\
Review of staging & 9 \\
Imaging features of malignancy & 9 \\
Prognosis & 7 \\
Distant metastases & 5 \\
Treatment planning & 4 \\
Early cancer & 3 \\
Cost-effectiveness & 1 \\
Restaging & 1 \\
Staging recurrent cancer & 1 \\
Correlation with tumour markers & 1 \\
Synchronous tumours & 1 \\
Texture analysis & 1 \\
\hline
\end{tabular}

The OC staging pathway is complex, utilising various modalities with different strengths and weaknesses. PET/CT is superior to CT for detection of distant metastases and influences the change of MDT management decisions in up to $38 \%$ of patients [109], whereas EUS is superior to CT for T-staging [110]. Comparison of techniques allows a modality to be tested against the perceived "gold-standard" staging investigation. This may reflect the desire for a simplified staging pathway with fewer investigations or the desire to increase evidence and awareness of a particular modality, thus introducing potential publication bias.

Influential articles are more likely to be cited by the scientific and clinical community. These citations form the basis of a journal's impact factor. The impact factor quantifies the average number of citations per manuscript published within that journal during a specific time period. Therefore, journals with a higher impact factor are recognised as being of higher quality and more likely to contain influential articles.

Radiological OC staging appeals to specialist radiologists and other members of the upper gastro-intestinal (GI) cancer MDT, and its clinical impact is great. The overall median 2014 and 5-year impact factors were 5.238 and 5.225, respectively, demonstrating that this field of research, often producing novel results, in a specific cancer population is not likely to be published in high-impact journals. The Journal of Clinical Oncology (JCO) had the highest 5-year impact factor (16.971) of articles in the 100 most cited.

In total, only 29 of the 100 most cited articles were published in radiology-related journals. This could represent the desire to achieve publication in a high-impact journal. The majority of radiology-related journals have impact factors $<5.00$. Only $16 \%$ of the top 100 articles were published in radiology-related journals with a 5-year impact factor $>5.00$ (Radiology, Journal of Nuclear Medicine and European Journal of Nuclear Medicine and Molecular Imaging). It may also reflect a lack of research conducted by radiologists, which is supported by evidence from a National Cancer Research Institute (NCRI) survey in 2012, which commented upon the lack of academic radiologists [111].

Many of the first authors $(n=65)$ are not affiliated to radiology departments, according to Thomas Reuters Web of Science citation indexing database. It is possible the authors work closely with a radiologist as part of the specialist Upper GI cancer MDT or have a clinical radiologist as a named co-author.

EUS was the most commonly investigated modality overall. This may be a reflection of the current reliance and importance of EUS for T and N staging, considered the current "gold standard" [110].

Despite EUS being the most frequently investigated modality, the ten articles with the highest citation rates all investigated functional PET imaging. The CT component of the $\mathrm{PET} / \mathrm{CT}$ examinations provided attenuation correction for 
Table 5 Ten articles with the highest citation rates

\begin{tabular}{|c|c|c|c|c|c|c|c|}
\hline Rank & Year & $\begin{array}{l}\text { Number of } \\
\text { citations }\end{array}$ & Citation rate & First author & Senior author & Title & Journal \\
\hline 1 & 2011 & 114 & 38.00 & Tixier F [47] & Visvikis D & $\begin{array}{l}\text { Intratumour heterogeneity characterized } \\
\text { by textural features on baseline } 18 \\
\text { F-FDG PET images predicts response } \\
\text { to concomitant radiochemotherapy in } \\
\text { oesophageal cancer }\end{array}$ & Journal of Nuclear Medicine \\
\hline 2 & 2010 & 146 & 36.50 & Rice TW [31] & Blackstone EH & $\begin{array}{l}\text { Cancer of the Oesophagus and Esophagogastric } \\
\text { Junction Data-Driven Staging for the Seventh } \\
\text { Edition of the American Joint Committee on } \\
\text { Cancer/International Union Against Cancer } \\
\text { Cancer Staging Manual }\end{array}$ & Cancer \\
\hline 3 & 2006 & 229 & 28.63 & Ott K [15] & Siewert JR & $\begin{array}{l}\text { Metabolic imaging predicts response, survival, } \\
\text { and recurrence in adenocarcinomas of the } \\
\text { esophagogastric junction }\end{array}$ & Journal of Clinical Oncology \\
\hline 4 & 2004 & 271 & 27.10 & Wieder HA [12] & Weber WA & $\begin{array}{l}\text { Time course of tumour metabolic activity during } \\
\text { chemoradiotherapy of oesophageal squamous } \\
\text { cell carcinoma and response to treatment }\end{array}$ & Journal of Clinical Oncology \\
\hline 5 & 2002 & 290 & 24.17 & Kinkel K [10] & Thoeni RF & $\begin{array}{l}\text { Detection of hepatic metastases from cancers of } \\
\text { the gastrointestinal tract by using noninvasive } \\
\text { imaging methods (US, CT, MR imaging, PET): } \\
\text { A meta-analysis }\end{array}$ & Radiology \\
\hline 5 & 2008 & 145 & 24.17 & van Vliet EPM [33] & Siersema PD & $\begin{array}{l}\text { Staging investigations for oesophageal cancer: } \\
\text { a meta-analysis }\end{array}$ & British Journal of Cancer \\
\hline 7 & 2000 & 306 & 21.86 & Flamen P [8] & Mortelmans L & $\begin{array}{l}\text { Utility of positron emission tomography for the } \\
\text { staging of patients with potentially operable } \\
\text { oesophageal carcinoma }\end{array}$ & Journal of Clinical Oncology \\
\hline 8 & 2010 & 84 & 21.00 & Hyun SH [77] & Kim BT & $\begin{array}{l}\text { Prognostic value of metabolic tumour volume } \\
\text { measured by } 18 \text { F-fluorodeoxyglucose positron } \\
\text { emission tomography in patients with oesophageal } \\
\text { carcinoma }\end{array}$ & Annals of Surgical Oncology \\
\hline 9 & 2003 & 193 & 17.55 & Downey RJ [18] & Rusch V & $\begin{array}{l}\text { Whole body (18)FDG-PET and the response } \\
\text { of oesophageal cancer to induction therapy: } \\
\text { Results of a prospective trial }\end{array}$ & Journal of Clinical Oncology \\
\hline 10 & 2004 & 168 & 16.80 & van Westreenen HL [23] & Plukker JTM & $\begin{array}{l}\text { Systematic review of the staging performance } \\
\text { of } 18 \text { F-fluorodeoxyglucose positron emission } \\
\text { tomography in oesophageal cancer }\end{array}$ & Journal of Clinical Oncology \\
\hline
\end{tabular}

PET data. Many PET/CT topics of research are relatively novel and have been described in other types of cancer. One of these topics, texture analysis, is the subject of the article with the highest citation rate [47]. Novel subjects are less likely to be published in high-impact journals, but may well be considered influential and provide the catalyst for future research.

Four of the PET/CT articles with the highest citation rates $[12,15,18,47]$ investigated its use in assessing treatment response. There is significant interest in the capability of metabolic imaging to assess for early treatment response, but these techniques have not been standardised for use outside of clinical research studies [112]. PET/CT scanning is expensive, and costly research could potentially only produce marginal long-term benefits for patients. The paradox of healthcare is that innovation increases expense, rather than producing more cost-effective and efficient processes, as is the case in industry [113]. These articles however are likely to be highly influential in forthcoming years, as the use of $\mathrm{PET} / \mathrm{CT}$ increases in cancer imaging.

This bibliometric analysis has a number of limitations. Citation rates can be misleading because of various biases, e.g. institutional, language or self-citation bias. Older articles tend to accrue more citations compared to newer research. We attempted to adjust for this by calculating a citation rate, which may provide information regarding the importance and potential influence that the research has. This in itself has limitations as the likelihood of citation rises with increasing numbers of published articles in peer-reviewed journals. Only articles written in English were included, which may have excluded some frequently cited research in other languages. Also, this study concentrated on radiological staging rather than other techniques such as endoscopy and laparoscopy.

The expanding volume of published literature has increased significantly over the past few decades. Between 1978 to 1985 and 1994 to 2001, the annual number of Medline articles increased by $46 \%$, particularly in the area of clinical research [114]. The annual rate of publication growth in PubMed Medline was 5.6 \% between 1997 and 2006, equating to a "doubling time" of 13 years [115]. This may explain the higher citation rate of PET/CT compared to that of EUS, as PET/CT is a more recent innovation. Overall, there are now more articles published per annum compared to previous years. This would therefore potentially increase the citation rate as a matter of course, not necessarily reflecting higher importance. 
As expected, the older articles only described $\mathrm{CT}$ and perhaps a review of the last 10 years of literature only may be more reflective of contemporary staging practice. Another limitation is that only the first and senior authors of the articles were included in the current analysis. It is possible that these authors contributed to other articles in this list, but would not have been counted during analysis. These authors may therefore be under-represented in terms of published article numbers and have had a greater influence on current $\mathrm{OC}$ staging.

Of the 29 articles comparing imaging techniques or modalities, 17 studies correlated imaging findings and histopathological diagnosis, widely regarded as the "gold standard". Limitations exist in radiological studies that compare new findings against a potentially inaccurate alternative imaging test. In this current study, articles that did not compare against pathological results included those investigating radiotherapy planning techniques and the diagnosis of distant metastases. In these studies, tissue was not necessarily sampled. There are several reasons why pathological confirmation is not possible. These include patients undergoing non-surgical management, which is true of the majority of cases of OC, and in situations where it would be unethical to obtain tissue purely for research purposes, such as in patients with unequivocal distant metastases.

There are further limitations of studies comparing imaging findings to histopathological specimens. Comparison of pretreatment imaging characteristics in patients receiving neoadjuvant therapy prior to surgery can be inaccurate, as the chemotherapy or radiotherapy may alter the morphology of the tumour. In this situation, a direct comparison is often not possible.

\section{Conclusion}

This bibliometric analysis describes the 100 most cited articles in the field of radiological OC staging investigations. Common topics of investigation include the accuracy of staging, comparison of modalities, treatment response and assessment of lymph nodes for metastases. The majority of articles are published outside of radiology-related journals, which may reflect the desire for high-impact publications or perhaps a lack of radiologists conducting imaging research. This study provides an understanding of research that has influenced current $\mathrm{OC}$ staging and citation rates may suggest important topics for future research, particularly validation studies of innovative techniques in larger patient populations.

Acknowledgments KF would like to acknowledge the support of the Wales Clinical Academic Training (WCAT) fellowship programme. No grant funding was used for this study and there are no conflicts of interest.
Open Access This article is distributed under the terms of the Creative Commons Attribution 4.0 International License (http:// creativecommons.org/licenses/by/4.0/), which permits unrestricted use, distribution, and reproduction in any medium, provided you give appropriate credit to the original author(s) and the source, provide a link to the Creative Commons license, and indicate if changes were made.

\section{References}

1. De Bellis N (2009) Bibliometrics and citation analysis: from the science citation index to cybermetrics. Scarecrow Press, Lanham, Maryland, USA

2. Kelly JC, Glynn RW, O’Briain DE, Felle P, McCabe JP (2010) The 100 classic papers of orthopaedic surgery: a bibliometric analysis. J Bone Joint Surg (Br) 92(10):1338-1343

3. Tas F (2014) An analysis of the most-cited research papers on oncology: which journals have they been published in? Tumour Biol 35(5):4645-4649

4. Cancer Research UK. Statistics and outlook for oesophageal cancer (2014) [updated December 8th 2014; accessed 11 June 2015] Available from: http://www.cancerresearchuk.org/cancer-help/ type/oesophageal-cancer/treatment/statistics-and-outlook-foroesophageal-cancer

5. Sobin L, Gospodarowicz M, Wittekind C (2009) UICC TNM classification of malignant tumours, 7th edn. Wiley, New York

6. Roberts SA, Kay C (2014) Oesophagus and stomach cancers. In: Nicholson T (ed) Recommendations for cross-sectional imaging in cancer management, 2nd edn. Royal College of Radiologists, London

7. Paladugu R, Schein M, Gardezi S, Wise L (2002) One hundred citation classics in general surgical journals. World J Surg 26(9): 1099-1105

8. Flamen P, Lerut A, Van Cutsem E, De Wever W, Peeters M, Stroobants S et al (2000) Utility of positron emission tomography for the staging of patients with potentially operable esophageal carcinoma. J Clin Oncol 18(18):3202-3210

9. Tio TL, Cohen P, Coene PP, Udding J, Jager F, Tytgat GNJ (1989) Endosonography and computed-tomography of esophageal-carcinoma-preoperative classification compared to the new (1987) TNM system. Gastroenterology 96(6):1478-1486

10. Kinkel K, Lu Y, Both M, Warren RS, Thoeni RF (2002) Detection of hepatic metastases from cancers of the gastrointestinal tract by using noninvasive imaging methods (US, CT, MR imaging, PET): a meta-analysis. Radiology 224(3):748-756

11. Catalano MF, Sivak MV, Rice T, Gragg LA, Vandam J (1994) Endosonographic features predictive of lymph-node metastasis. Gastrointest Endosc 40(4):442-446

12. Wieder HA, Brucher B, Zimmermann F, Becker K, Lordick F, Beer A et al (2004) Time course of tumor metabolic activity during chemoradiotherapy of esophageal squamous cell carcinoma and response to treatment. J Clin Oncol 22(5):900-908

13. Botet JF, Lightdale CJ, Zauber AG, Gerdes H, Urmacher C, Brennan MF (1991) Preoperative staging of esophageal cancer - comparison of endoscopic US and dynamic CT. Radiology 181(2):419-425

14. Skinner DB, Little AG, Ferguson MK, Soriano A, Staszak VM (1986) Selection of operation for esophageal cancer based on staging. Ann Surg 204(4):391-401

15. Ott K, Weber WA, Lordick F, Becker K, Busch R, Herrmann K et al (2006) Metabolic imaging predicts response, survival, and recurrence in adenocarcinomas of the esophagogastric junction. $\mathrm{J}$ Clin Oncol 24(29):4692-4698

16. Bhutani MS, Hawes RH, Hoffman BJ (1997) A comparison of the accuracy of echo features during endoscopic ultrasound (EUS) 
and EUS-guided fine-needle aspiration for diagnosis of malignant lymph node invasion. Gastrointest Endosc 45(6):474-479

17. Flamen P, Van Cutsem E, Lerut A, Cambier JP, Haustermans K, Bormans $\mathrm{G}$ et al (2002) Positron emission tomography for assessment of the response to induction radiochemotherapy in locally advanced oesophageal cancer. Ann Oncol 13(3):361-368

18. Downey RJ, Akhurst T, Ilson D, Ginsberg R, Bains MS, Gonen M et al (2003) Whole body (18)FDG-PET and the response of esophageal cancer to induction therapy: results of a prospective trial. $\mathrm{J}$ Clin Oncol 21(3):428-432

19. Flanagan FL, Dehdashti F, Siegel BA, Trask DD, Sundaresan SR, Patterson GA et al (1997) Staging of esophageal cancer with F-18fluorodeoxyglucose positron emission tomography. AJR Am J Roentgenol 168(2):417-424

20. Picus D, Balfe DM, Koehler RE, Roper CL, Owen JW (1983) Computed-tomography in the staging of esophageal-carcinoma. Radiology 146(2):433-438

21. Rosch T (1995) Endosonographic staging of esophageal cancer: a review of literature results. Gastrointest Endosc Clin N Am 5(3): 537-547

22. Kelly S, Harris KM, Berry E, Hutton J, Roderick P, Cullingworth J et al (2001) A systematic review of the staging performance of endoscopic ultrasound in gastro-oesophageal carcinoma. Gut 49(4):534-539

23. van Westreenen HL, Westerterp M, Bossuyt PM, Pruim J, Sloof GW, van Lanschot JJ et al (2004) Systematic review of the staging performance of $18 \mathrm{~F}$-fluorodeoxyglucose positron emission tomography in esophageal cancer. J Clin Oncol 22(18):3805-3812

24. May A, Gunter E, Roth F, Gossner L, Stolte M, Vieth M et al (2004) Accuracy of staging in early oesophageal cancer using high resolution endoscopy and high resolution endosonography: a comparative, prospective, and blinded trial. Gut 53(5):634-640

25. Lerut T, Flamen P, Ectors N, Van Cutsem E, Peeters M, Hiele M et al (2000) Histopathologic validation of lymph node staging with FDG-PET scan in cancer of the esophagus and gastroesophageal junction - a prospective study based on primary surgery with extensive lymphadenectomy. Ann Surg 232(6):743-751

26. Kato H, Kuwano H, Nakajima M, Miyazaki T, Yoshikawa M, Ojima $\mathrm{H}$ et al (2002) Comparison between positron emission tomography and computed tomography in the use of the assessment of esophageal carcinoma. Cancer 94(4):921-928

27. Block MI, Patterson GA, Sundaresan RS, Bailey MS, Flanagan FL, Dehdashti F et al (1997) Improvement in staging of esophageal cancer with the addition of positron emission tomography. Ann Thorac Surg 64(3):770-776

28. Swisher SG, Maish M, Erasmus JJ, Correa AM, Ajani JA, Bresalier R et al (2004) Utility of PET, CT, and EUS to identify pathologic responders in esophageal cancer. Ann Thorac Surg 78(4):1152-1160

29. Swisher SG, Erasmus J, Maish M, Correa AM, Macapinlac H, Ajani JA et al (2004) 2-fluoro-2-deoxy-D-glucose positron emission tomography imaging is predictive of pathologic response and survival after preoperative chemoradiation in patients with esophageal carcinoma. Cancer 101(8):1776-1785

30. Luketich JD, Friedman DM, Weigel TL, Meehan MA, Keenan RJ, Townsend DW et al (1999) Evaluation of distant metastases in esophageal cancer: 100 consecutive positron emission tomography scans. Ann Thorac Surg 68(4):1133-1136

31. Rice TW, Rusch VW, Ishwaran H, Blackstone EH, Collaboration WEC (2010) Cancer of the esophagus and esophagogastric junction data-driven staging for the seventh edition of the American Joint Committee on Cancer/International Union Against Cancer Cancer Staging Manuals. Cancer 116(16):3763-3773

32. Vilgrain V, Mompoint D, Palazzo L, Menu Y, Gayet B, Ollier P et al (1990) Staging of esophageal-carcinoma - comparison of results with endoscopic sonography and CT. AJR Am J Roentgenol 155(2):277-281
33. van Vliet EP, Heijenbrok-Kal MH, Hunink MG, Kuipers EJ, Siersema PD (2008) Staging investigations for oesophageal cancer: a meta-analysis. Br J Cancer 98(3):547-557

34. Rosch T, Lorenz R, Zenker K, Vonwichert A, Dancygier H, Hofler $\mathrm{H}$ et al (1992) Local staging and assessment of resectability in carcinoma of the esophagus, stomach, and duodenum by endoscopic ultrasonography. Gastrointest Endosc 38(4):460-467

35. Ziegler K, Sanft C, Zeitz M, Friedrich M, Stein H, Haring R et al (1991) Evaluation of endosonography in TN staging of esophageal cancer. Gut 32(1):16-20

36. Kole AC, Plukker JT, Nieweg OE, Vaalburg W (1998) Positron emission tomography for staging of oesophageal and gastroesophageal malignancy. Br J Cancer 78(4):521-527

37. Luketich JD, Schauer PR, Meltzer CC, Landreneau RJ, Urso GK, Townsend DW et al (1997) Role of positron emission tomography in staging esophageal cancer. Ann Thorac Surg 64(3):765-769

38. Buskens CJ, Westerterp M, Lagarde SM, Bergman J, ten Kate FJW, van Lanschot JJB (2004) Prediction of appropriateness of local endoscopic treatment for high-grade dysplasia and early adenocarcinoma by EUS and histopathologic features. Gastrointest Endosc 60(5):703-710

39. Watt I, Stewart I, Anderson D, Bell G, Anderson JR (1989) Laparoscopy, ultrasound and computed-tomography in cancer of the esophagus and gastric cardia - a prospective comparison for detecting intra-abdominal metastases. Br J Surg 76(10):1036-1039

40. Moss AA, Schnyder P, Thoeni RF, Margulis AR (1981) Esophageal-carcinoma-pre-therapy staging by computed-tomography. AJR Am J Roentgenol 136(6):1051-1056

41. Zuccaro G, Rice TW, Goldblum J, Medendorp SV, Becker M, Pimentel R et al (1999) Endoscopic ultrasound cannot determine suitability for esophagectomy after aggressive chemoradiotherapy for esophageal cancer. Am J Gastroenterol 94(4):906-912

42. Grimm H, Binmoeller KF, Hamper K, Koch J, Hennebruns D, Soehendra N (1993) Endosonography for preoperative locoregional staging of esophageal and gastric-cancer. Endoscopy 25(3):224-230

43. Vazquez-Sequeiros E, Wiersema MJ, Clain JE, Norton ID, Levy MJ, Romero Y et al (2003) Impact of lymph node staging on therapy of esophageal carcinoma. Gastroenterology 125(6):1626-1635

44. Yoon YC, Lee KS, Shim YM, Kim BT, Kim K, Kim TS (2003) Metastasis to regional lymph nodes in patients with esophageal squamous cell carcinoma: CT versus FDG PET for presurgical detection - prospective study. Radiology 227(3):764-770

45. Tio TL, Tytgat GN (1984) Endoscopic ultrasonography in the assessment of intramural and transmural infiltration of tumors in the esophagus, stomach and papilla of vater and in the detection of extraesophageal lesions. Endoscopy 16(6):203-210

46. Cerfolio RJ, Bryant AS, Ohja B, Bartolucci AA, Eloubeidi MA (2005) The accuracy of endoscopic ultrasonography with fineneedle aspiration, integrated positron emission tomography with computed tomography, and computed tomography in restaging patients with esophageal cancer after neoadjuvant chemoradiotherapy. J Thorac Cardiovasc Surg 129(6):1232-1241

47. Tixier F, Le Rest CC, Hatt M, Albarghach N, Pradier O, Metges JP et al (2011) Intratumor heterogeneity characterized by textural features on baseline 18F-FDG PET images predicts response to concomitant radiochemotherapy in esophageal cancer. J Nucl Med 52(3):369-378

48. Vazquez-Sequeiros E, Norton ID, Clain JE, Wang KK, Affi A, Allen M et al (2001) Impact of EUS-guided fine-needle aspiration on lymph node staging in patients with esophageal carcinoma. Gastrointest Endosc 53(7):751-757

49. Dittler HJ, Siewert JR (1993) Role of endoscopic ultrasonography in esophageal-carcinoma. Endoscopy 25(2):156-161

50. Rasanen JV, Sihvo EI, Knuuti MJ, Minn HR, Luostarinen ME, Laippala P et al (2003) Prospective analysis of accuracy of positron emission tomography, computed tomography, and endoscopic ultrasonography in staging of adenocarcinoma of the esophagus and the esophagogastric junction. Ann Surg Oncol 10(8):954-960 
51. Quint LE, Hepburn LM, Francis IR, Whyte RI, Orringer MB (1995) Incidence and distribution of distant metastases from newly-diagnosed esophageal-carcinoma. Cancer 76(7):1120-1125

52. Reed CE, Mishra G, Sahai AV, Hoffman BJ, Hawes RH (1999) Esophageal cancer staging: improved accuracy by endoscopic ultrasound of celiac lymph nodes. Ann Thorac Surg 67(2):319-321

53. Choi JY, Lee KH, Shim YM, Lee KS, Kim JJ, Kim SE et al (2000) Improved detection of individual nodal involvement in squamous cell carcinoma of the esophagus by FDG PET. J Nucl Med 41(5): 808-815

54. Rankin SC, Taylor H, Cook GJ, Mason R (1998) Computed tomography and positron emission tomography in the pre-operative staging of oesophageal carcinoma. Clin Radiol 53(9):659-665

55. Thompson WM, Halvorsen RA, Foster WL, Williford ME, Postlethwait RW, Korobkin M (1983) Computed-tomography for staging esophageal and gastroesophageal cancer-reevaluation. AJR Am J Roentgenol 141(5):951-958

56. Wallace MB, Nietert PJ, Earle C, Krasna MJ, Hawes RH, Hoffman BJ et al (2002) An analysis of multiple staging management strategies for carcinoma of the esophagus: computed tomography, endoscopic ultrasound, positron emission tomography, and thoracoscopy/laparoscopy. Ann Thorac Surg 74(4):1026-1032

57. Quint LE, Glazer GM, Orringer MB, Gross BH (1985) Esophagealcarcinoma - CT findings. Radiology 155(1):171-175

58. Kato H, Miyazaki T, Nakajima M, Takita J, Kimura H, Faried A et al (2005) The incremental effect of positron emission tomography on diagnostic accuracy in the initial staging of esophageal carcinoma. Cancer 103(1):148-156

59. Larghi A, Lightdale CJ, Memeo L, Bhagat G, Okpara N, Rotterdam H (2005) EUS followed by EMR for staging of highgrade dysplasia and early cancer in Barrett's esophagus. Gastrointest Endosc 62(1):16-23

60. Takashima S, Takeuchi N, Shiozaki H, Kobayashi K, Morimoto S, Ikezoe J et al (1991) Carcinoma of the esophagus: CT vs MR imaging in determining resectability. AJR Am J Roentgenol 156(2):297-302

61. van Westreenen HL, Cobben DCP, Jager PL, van Dullemen HM, Wesseling J, Elsinga PH et al (2005) Comparison of F-18-FLT PET and F-18-FDG PET in esophageal cancer. J Nucl Med 46(3):400-404

62. Eloubeidi MA, Wallace MB, Reed CE, Hadzijahic N, Lewin DN, Van Velse A et al (2001) The utility of EUS and EUS-guided fine needle aspiration in detecting celiac lymph node metastasis in patients with esophageal cancer: a single-center experience. Gastrointest Endosc 54(6):714-719

63. Hasegawa N, Niwa Y, Arisawa T, Hase S, Goto H, Hayakawa T (1996) Preoperative staging of superficial esophageal carcinoma: comparison of an ultrasound probe and standard endoscopic ultrasonography. Gastrointest Endosc 44(4):388-393

64. Levine EA, Farmer MR, Clark P, Mishra G, Ho C, Geisinger KR et al (2006) Predictive value of 18-fluoro-deoxy-glucose-positron emission tomography (F-18-FDG-PET) in the identification of responders to chemoradiation therapy for the treatment of locally advanced esophageal cancer. Ann Surg 243(4):472-478

65. Rice TW, Boyce GA, Sivak MV (1991) Esophageal ultrasound and the preoperative staging of carcinoma of the esophagus. $\mathrm{J}$ Thorac Cardiovasc Surg 101(3):536-544

66. Isenberg G, Chak A, Canto MI, Levitan N, Clayman J, Pollack BJ et al (1998) Endoscopic ultrasound in restaging of esophageal cancer after neoadjuvant chemoradiation. Gastrointest Endosc 48(2):158-163

67. Leong T, Everitt C, Yuen K, Condron S, Hui A, Ngan SYK et al (2006) A prospective study to evaluate the impact of FDG-PET on CT-based radiotherapy treatment planning for oesophageal cancer. Radiother Oncol 78(3):254-261
68. Puli SR, Reddy JBK, Bechtold ML, Antillon D, Ibdah JA, Antillon MR (2008) Staging accuracy of esophageal cancer by endoscopic ultrasound: a meta-analysis and systematic review. World J Gastroenterol 14(10):1479-1490

69. Flamen P, Lerut A, van Custem E, Cambier JP, Maes A, De Wever W et al (2000) The utility of positron emission tomography for the diagnosis and staging of recurrent esophageal cancer. J Thorac Cardiovasc Surg 120(6):1085-1092

70. Lightdale CJ, Kulkarni KG (2005) Role of endoscopic ultrasonography in the staging and follow-up of esophageal cancer. J Clin Oncol 23(20):4483-4489

71. Daffner RH, Halber MD, Postlethwait RW, Korobkin M, Thompson WM (1979) CT of the esophagus. 2. Carcinoma. AJR Am J Roentgenol 133(6):1051-1055

72. Kim K, Park SJ, Kim BT, Lee KS, Shim YM (2001) Evaluation of lymph node metastases in squamous cell carcinoma of the esophagus with positron emission tomography. Ann Thorac Surg 71(1): 290-294

73. Meltzer CC, Luketich JD, Friedman D, Charron M, Strollo D, Meehan M et al (2000) Whole-body FDG positron emission tomographic imaging for staging esophageal cancer-comparison with computed tomography. Clin Nucl Med 25(11):882-887

74. Vrieze O, Haustermans K, De Wever W, Lerut T, Van Cutsem E, Ectors $\mathrm{N}$ et al (2004) Is there a role for FGD-PET in radiotherapy planning in esophageal carcinoma? Radiother Oncol 73(3): 269-275

75. Jones DR, Parker LA, Detterbeck FC, Egan TM (1999) Inadequacy of computed tomography in assessing patients with esophageal carcinoma after induction chemoradiotherapy. Cancer 85(5):1026-1032

76. Chak A, Canto M, Gerdes H, Lightdale CJ, Hawes RH, Wiersema MJ et al (1995) Prognosis of esophageal cancers preoperatively staged to be locally invasive (T4) by endoscopic ultrasound (EUS) - a multicenter retrospective cohort study. Gastrointest Endosc 42(6):501-506

77. Hyun SH, Choi JY, Shim YM, Kim K, Lee SJ, Cho YS et al (2010) Prognostic value of metabolic tumor volume measured by $18 \mathrm{~F}$-fluorodeoxyglucose positron emission tomography in patients with esophageal carcinoma. Ann Surg Oncol 17(1):115-122

78. Quint LE, Glazer GM, Orringer MB (1985) Esophageal imaging by MR and CT: study of normal anatomy and neoplasms. Radiology 156(3):727-731

79. Murata Y, Muroi M, Yoshida M, Ide H, Hanyu F (1987) Endoscopic ultrasonography in the diagnosis of esophageal carcinoma. Surg Endosc 1(1):11-16

80. Hiele M, DeLeyn P, Schurmans P, Lerut A, Huys S, Geboes K et al (1997) Relation between endoscopic ultrasound findings and outcome of patients with tumors of the esophagus or esophagogastric junction. Gastrointest Endosc 45(5):381-386

81. Wakelin SJ, Deans C, Crofts TJ, Allan PL, Plevris JN, PatersonBrown S (2002) A comparison of computerised tomography, laparoscopic ultrasound and endoscopic ultrasound in the preoperative staging of oesophago-gastric carcinoma. Eur J Radiol 41(2):161-167

82. Scotiniotis IA, Kochman ML, Lewis JD, Furth EE, Rosato EF, Ginsberg GG (2001) Accuracy of EUS in the evaluation of Barrett's esophagus and high-grade dysplasia or intramucosal carcinoma. Gastrointest Endosc 54(6):689-696

83. Fockens P, Van den Brande JHM, van Dullemen HM, van Lanschot JJB, Tytgat GNJ (1996) Endosonographic T-staging of esophageal carcinoma: a learning curve. Gastrointest Endosc 44(1):58-62

84. Beseth BD, Bedford R, Isacoff WH, Holmes EC, Cameron RB (2000) Endoscopic ultrasound does not accurately assess pathologic stage of esophageal cancer after neoadjuvant chemoradiotherapy. Am Surg 66(9):827-831 
85. Catalano MF, Alcocer E, Chak A, Nguyen CC, Raijman I, Geenen JE et al (1999) Evaluation of metastatic celiac axis lymph nodes in patients with esophageal carcinoma: accuracy of EUS. Gastrointest Endosc 50(3):352-356

86. Giovannini M, Monges G, Seitz JF, Moutardier V, Bernardini D, Thomas P et al (1999) Distant lymph node metastases in esophageal cancer: impact of endoscopic ultrasound-guided biopsy. Endoscopy 31(7):536-540

87. Rice TW (2000) Clinical staging of esophageal carcinoma. CT, EUS, and PET. Chest Surg Clin N Am 10(3):471-485

88. Heeren PAM, Jager PL, Bongaerts F, van Dullemen H, Sluiter W, Plukker JTM (2004) Detection of distant metastases in esophageal cancer with F-18-FDG PET. J Nucl Med 45(6):980-987

89. Rizk N, Downey RJ, Akhurst T, Gonen M, Bains MS, Larson S et al (2006) Preoperative 18[F]-fluorodeoxyglucose positron emission tomography standardized uptake values predict survival after esophageal adenocarcinoma resection. Ann Thorac Surg 81(3): 1076-1081

90. Kostakoglu L, Goldsmith SJ (2004) PET in the assessment of therapy response in patients with carcinoma of the head and neck and of the esophagus. J Nucl Med 45(1):56-68

91. Moureau-Zabotto L, Touboul E, Lerouge D, Deniaud-Alexandre E, Grahek D, Foulquier JN et al (2005) Impact of CT and F-18deoxyglucose positron emission tomography image fusion for conformal radiotherapy in esophageal carcinoma. Int J Radiat Oncol Biol Phys 63(2):340-345

92. Pech O, May A, Guenter E, Gossner L, Ell C (2006) The impact of endoscopic ultrasound and computed tomography on the TNM staging of early cancer in Barrett's esophagus. Am J Gastroenterol 101(10):2223-2229

93. Choi JY, Jang HJ, Shim YM, Kim K, Lee KS, Lee KH et al (2004) 18 F-FDG PET in patients with esophageal squamous cell carcinoma undergoing curative surgery: prognostic implications. J Nucl Med 45(11): 1843-1850

94. Lehr L, Rupp N, Siewert JR (1988) Assessment of resectability of esophageal cancer by computed tomography and magnetic resonance imaging. Surgery 103(3):344-350

95. Lightdale CJ (1992) Endoscopic ultrasonography in the diagnosis, staging and follow-up of esophageal and gastric-cancer. Endoscopy 24:297-303

96. Kobori D, Kirihara Y, Kosaka N, Hara T (1999) Positron emission tomography of esophageal carcinoma using C-11-choline and F18-fluorodeoxyglucose - a novel method of preoperative lymph node staging. Cancer 86(9):1638-1648

97. Luketich JD, Schauer P, Landreneau R, Nguyen N, Urso K, Ferson $P$ et al (1997) Minimally invasive surgical staging is superior to endoscopic ultrasound in detecting lymph node metastases in esophageal cancer. J Thorac Cardiovasc Surg 114(5):817-821

98. Lowe VJ, Booya F, Fletcher JG, Nathan M, Jensen E, Mullan B et al (2005) Comparison of positron emission tomography, computed tomography, and endoscopic ultrasound in the initial staging of patients with esophageal cancer. Mol Imaging Biol 7(6):422-430

99. Song SY, Kim JH, Ryu JS, Lee GTH, Kim SB, Park SI et al (2005) FDG-PET in the prediction of pathologic response after neoadjuvant chemoradiotherapy in locally advanced, resectable esophageal cancer. Int J Radiat Oncol Biol Phys 63(4):1053-1059

100. Yuan S, Yu Y, Chao KS, Fu Z, Yin Y, Liu T et al (2006) Additional value of PET/CT over PET in assessment of locoregional lymph nodes in thoracic esophageal squamous cell cancer. J Nucl Med 47(8):1255-1259
101. Bar-Shalom R, Guralnik L, Tsalic M, Leiderman M, Frenkel A, Gaitini D et al (2005) The additional value of PET/CT over PET in FDG imaging of oesophageal cancer. Eur J Nucl Med Mol Imaging 32(8):918-924

102. McAteer D, Wallis F, Couper G, Norton M, Welch A, Bruce D et al (1999) Evaluation of F-18-FDG positron emission tomography in gastric and oesophageal carcinoma. Br J Radiol 72(858): 525-529

103. van Westreenen HL, Westerterp M, Jager PL, van Dullemen HM, Sloof GW, Comans EFI et al (2005) Synchronous primary neoplasms detected on F-18-FDG PET in staging of patients with esophageal cancer. J Nucl Med 46(8):1321-1325

104. Eloubeidi MA, Wallace MB, Hoffman BJ, Leveen MB, Van Velse A, Hawes RH et al (2001) Predictors of survival for esophageal cancer patients with and without celiac axis lymphadenopathy: impact of staging endosonography. Ann Thorac Surg 72(1):212-218

105. Konski A, Doss M, Milestone B, Haluszka O, Hanlon A, Freedman $G$ et al (2005) The integration of 18-fluoro-deoxyglucose positron emission tomography and endoscopic ultrasound in the treatment-planning process for esophageal carcinoma. Int $\mathrm{J}$ Radiat Oncol Biol Phys 61(4):1123-1128

106. Meyers BF, Downey RJ, Decker PA, Keenan RJ, Siegel BA, Cerfolio RJ et al (2007) The utility of positron emission tomography in staging of potentially operable carcinoma of the thoracic esophagus: results of the American College of Surgeons Oncology Group Z0060 trial. J Thorac Cardiovasc Surg 133(3): 738-745

107. Wu LF, Wang BZ, Feng JL, Cheng WR, Liu GR, Xu XH et al (2003) Preoperative TN staging of esophageal cancer: comparison of miniprobe ultrasonography, spiral CT and MRI. World J Gastroenterol 9(2):219-224

108. Ferlay J, Soerjomataram I, Dikshit R, Eser S, Mathers C, Rebelo $M$ et al (2015) Cancer incidence and mortality worldwide: sources, methods and major patterns in GLOBOCAN 2012. Int J Cancer 136(5):E359-386

109. Blencowe NS, Whistance RN, Strong S, Hotton EJ, Ganesh S, Roach H et al (2013) Evaluating the role of fluorodeoxyglucose positron emission tomography-computed tomography in multidisciplinary team recommendations for oesophago-gastric cancer. Br J Cancer 109(6):1445-1450

110. Tangoku A, Yamamoto Y, Furukita Y, Goto M, Morimoto M (2012) The new era of staging as a key for an appropriate treatment for esophageal cancer. Ann Thorac Cardiovasc Surg 18(3):190-199

111. National Cancer Research Institute (NCRI) (2012) Imaging research in the UK: An NCRI survery [accessed 16 Dec 2015]; Available from: http://www.ncri.org.uk/publication/imagingresearch-in-the-uk-an-ncri-survey-2/

112. Schmidt T, Lordick F, Herrmann K, Ott K (2015) Value of functional imaging by PET in esophageal cancer. J Natl Compr Cancer Netw 13(2):239-247

113. Skinner JS (2013) The costly paradox of health-care technology. MIT technology review business report [accessed 16 Dec 2015] Available from: http://www.technologyreview.com/news/518876/ the-costly-paradox-of-health-care-technology/

114. Druss BG (2005) Growth and decentralization of the medical literature: implications for evidence-based medicine. J Med Libr Assoc 93(4):499-501

115. Larsen PO, von Ins M (2010) The rate of growth in scientific publication and the decline in coverage provided by science citation index. Scientometrics 84:575-603 